\title{
TOWARDS AN INTEGRATED SCIENCE OF AESTHETICS. GETTING RID OF THE MAIN MISUNDERSTANDINGS IN EVOLUTIONARY AESTHETICS ${ }^{1}$
}

\section{PARA UMA CIÊNCIA INTEGRADA DA ESTÉTICA: ABANDONANDO OS PRINCIPAIS MAL-ENTENDIDOS DA ESTÉTICA EVOLUCIONÁRIA}

Mariagrazia Portera

Università degli Studi di Firenze, Italia

Abstract: Evolutionary Aesthetics is a bourgeoning and thriving sub-field of Aesthetics, the main aim of which is "the importation of aesthetics into natural sciences, and especially its integration into the heuristic of Darwin's evolutionary theory." Notwithstanding the growing popularity in the past two decades, a look into the state of current research in Evolutionary Aesthetics suggests a significant degree of haziness in the field from both epistemologicalmethodological and theoretical points of view. The main aim of the present paper is to evaluate consistency and coherence of the Evolutionary Aesthetics' research programme against the background of Boix Mansilla's epistemic criteria for interdisciplinary research programmes, and to assess the potential of epigenetics and niche construction theory as two new promising research avenues in a revised, updated Evolutionary Aesthetics.

Keywords: Interdisciplinarity; Evolution; Niche; Epigenetics; Darwin; Epistemology.

Resumo: A Estética Evolucionária é um inovador e próspero subcampo da Estética, sendo seu principal objetivo "a passagem da estética para as ciências naturais e, em especial, sua integração na heurística da teoria evolutiva de Darwin”. Apesar de sua crescente popularidade nas últimas duas décadas, um olhar atento sobre o estado atual da pesquisa em Estética Evolucionária sugere um grau significativo de nebulosidade no campo, tanto do ponto de vista metodológicoepistemológico quanto da perspectiva teórica. O objetivo principal do presente artigo é avaliar a consistência e a coerência do programa de pesquisa da Estética Evolucionária em contraste com o escopo dos critérios epistemológicos de Boix Mansilla para programas de pesquisa interdisciplinar, além de avaliar o potencial da Epigenética e da Teoria da Construção de Nicho como dois novos e promissores caminhos de pesquisa para uma revisada e atualizada Estética Evolucionária.

Palavras-chave: interdisciplinaridade; evolução; nicho; epigenética; Darwin; epistemologia.

\footnotetext{
${ }^{1}$ Nota do editor: este artigo já foi publicado na revista italiana Aisthesis. Pratiche, linguaggi e saperi dell'estetico, n. 8/1 (2015), p. 194-203.
} 


\section{Introduction}

Since its foundation as a separate branch of philosophy in the late Eighteenth century, Aesthetics has been shaped by the overlap with biological, physiological and "neurological" (ante litteram) discourses (BURKE, 1757; KANT, 1790; AVANESSIAN, MENNINGHAUS, VÖLKER 2009). The same overlap stands out noticeably in Charles DARWIN's groundbreaking Origin of Species (1859), "aesthetically constructed" according to KOHN (1996) (see MENNINGHAUS, 2011; PRUM, 2012; WELSCH, 2012). The Descent of Man (DARWIN, 1871), rich in concepts and expressions drawn from the Eighteenth- and Nineteenth-century English aestheticphilosophical debate, is perhaps one of the first studies where relevant issues about the origin of human sense of beauty are answered with explicit recourse to the nervous system (the brain) and its evolution. Attempting to find a suitable explanation for the various sensations of pleasure and for the emotional and intellectual capacities required by aesthetic sense, DARWIN writes that " there must be some fundamental cause in the constitution of the nervous system" (in The Descent of Man; WELSCH, 2004).

Contemporary endeavours to investigate aesthetic topics through the lens of evolutionary theory and neuroscience - that is, adopting an interdisciplinary research methodology and working on the boundary between Humanities and the Natural Sciences, between philosophical aesthetics, neurosciences and evolutionary biology - appear therefore legitimate and even indispensable, in the light of the history of the discipline itself.

Indeed, Evolutionary Aesthetics (VOLAND, GRAMMER, 2003; DUTTON, 2009; DAVIES, 2012) and Neuroaesthetics (ZEKI, 1993, 2008; ZEKI, KAWABATA, 2004) are today two thriving interdisciplinary research fields (LEDER, 2013; NADAL, SKOV, 2013; LEDER, NADAL, 2014; DAVIES, 2012), both in their early days, still struggling for a shared, defined and tenable research program. Promises and pitfalls go hand in hand (CROFT, 2011; DAVIES, 2012).

The aim of this overview, which will focus in particular on Evolutionary Aesthetics (EA), is twofold: it attempts firstly to assess the state of the art of contemporary EA and to highlight its main epistemological, theoretical and methodological difficulties; secondly, to assess the impact on EA of rather recent developments in evolutionary biology (for reasons of space, I will restrict myself to discussing only two topics: epigenetics and 
niche construction theory), suggesting that they can provide new avenues for research in EA.

\section{Evolutionary Aesthetics today}

According to Voland, Grammer (2003), EA's main aim is “ the importation of aesthetics into natural sciences, and especially its integration into the heuristic of Darwin's evolutionary theory " (VOLAND, GRAMMER, 2003, p. 5; VOLAND, RUSCH, 2013). Scholars working in the field attempt to determine, through the adoption of an interdisciplinary research methodology, whether and to what extent Darwinian evolution can shed light on our capacity to have aesthetic experiences, make aesthetic judgments (both of art and natural beauty) and produce literary, visual, musical artworks.

Broadly speaking, current EA provides a set of three main accounts for the emergence of an aesthetic attitude in humans:

a) An adaptive account, further specified into three sub accounts:

a.1.) A sub account relying directly on the action of natural selection and mainly focused on human aesthetic preferences (for physical traits in other sex or for natural features in the landscape), according to which aesthetic preferences evolved because they reliably signal fecundity and superior genetic quality in potential sexual partners or a suitable environment to live in (VOLAND, GRAMMER, 2003; VOLAND, RUSCH, 2013; LEWIS D., RUSSELL E., AL-SHAWAF L., BUSS D., 2015; ORIANS, 1986);

a.2) An operational (meta-)sub account, claiming that the aesthetic attitude (including artistic behaviour) evolved because it improves our cognitive performances and contributes to the "testing" and "tuning" of our perceptual and cognitive machinery (TOOBY, COSMIDES, 2001; moving from Tooby and Cosmides, but expanding their viewpoint and focusing on the role and significance of imagination for human life, see also CARROLL, 2004; 2012; 2013);

a.3) A pro-sociallemotional sub account, claiming that the aesthetic attitude (including artistic behaviour) evolved because it fosters social cohesion and cooperation among the member of a group (DISSANAYAKE, 1988; 1992; 2000; human artistic/aesthetic behaviour seems to be thus not an individual, rather a group adaptation); 
b) An account based on sexual selection, according to which the aesthetic evolved in our human ancestors because of its contribution to their reproductive success, at the same time reducing, instead of increasing, their chances of survival (MILLER, 2000; ROTHENBERG, 2011);

c) An account based on the concept of by-product, according to which human aesthetic attitude is the unforeseen result of the combined activity of more fundamental human species-specific adaptations (language, highly complex cognitive performances, tool-making, symbolic thought) (MITHEN, 1996; PINKER, 1997) ${ }^{2}$.

I suggest here to assess the quality of EA's main accounts by applying BOIX MANSILLA's (2006a, b) epistemic criteria for evaluating interdisciplinary research programs in general (CROFT, 2011). These criteria are: a. consistency, i.e. the interdisciplinary work (in our case, EA) should be consistent with what researchers in each of the different disciplines involved (in this case, mainly evolutionary biology and philosophical aesthetics) know and find tenable; b. balance, requiring a reasonable compromise between the insights and state of the art of each discipline involved (hypersimplification of either one or the other is to be avoided); c. effectiveness, i.e. the interdisciplinary research work should produce theoretical or practical advancements that would have not been possible remaining within the boundaries of a single discipline.

In the light of Boix Mansilla's epistemic criteria, I claim that none of the main EA accounts summarised above is fully satisfactory (DAVIES, 2012).

\section{Four main difficulties}

1) Although at various degrees, the accounts summarised above generally assume the concepts of "aesthetic" and "art" in a rather simplified and shallow meaning, eventually inconsistent with cutting-edge research in Aesthetics and Philosophy of Art. There are more than a few scholars in EA (VOLAND, GRAMMER, 2003; BUSS, 2005; LEWIS et al. 2015) who conceptualise the aesthetic as merely reducing to preferences (likings) of one thing more than others, for instance a colour or a physical trait.

${ }^{2}$ See also CHATTERJEE 2014, who provides a non-adaptationist account of the aesthetic behaviour (following DEACON 2010 and applying the concept of "relaxed selection"). 
Moreover, researchers often use "art" and "aesthetic" in close connection or even interchangeably (LEDER, NADAL, 2014), simply overlooking the relevant differences between the two terms and assuming them in a too broad, eventually fruitless meaning. As DISSANAYAKE writes in her paper (2014), "It is not enough to treat our subject [the arts and the aesthetic behaviour, M.P.] with a "cluster definition" (DUTTON, 2009), if we wish to suggest an origin and adaptive function (or functions). We have to know what we are talking about and looking for" (DISSANAYAKE, 2014: 44). Such a commitment to a clear and comprehensive definition (or, at least, to the search for it) of the notions of "art" and "aesthetic" is frankly an exception in the field of contemporary EA ${ }^{3}$.

2) If we turn to the scientific side, the situation does not change fundamentally: current EA appears still to refer to a simplified version of the evolutionary theory, largely structured along the model and patterns of Evolutionary Psychology (BARKOW, COSMIDES, TOOBY, 1992; PINKER, 1997; for a critical approach: SCHER, RAUSCHER, 2003; BULLER, 2005; RICHARDSON, 2007; BOLHUIS et al., 2011). The abuse of the concept of adaptation (CARROLL, 2013), a shallow understanding of the concepts of exaptation and spandrel (GOULD, VRBA, 1982; GOULD, 2002), the common reference to a "mythical" Pleistocene environment (BOLHUIS, et al. 2011) assumed as the homogeneous age and habitat in which the genus Homo is supposed to have emerged for the first time, a rather externalist and gene-centred conception of the action of natural selection make current EA almost inconsistent with what researchers in Evolutionary biology know and find tenable today. The first epistemic criterion is not really met by current EA. As a simplified version of the aesthetic theory (1) is integrated with a rather simplified version of the evolutionary theory, the resulting interdisciplinary product (current EA) seems to be not balanced enough (it does not meet Boix Mansilla's second epistemic criterion).

3) EA's research program is mainly restricted to Homo sapiens: so

\footnotetext{
${ }^{3}$ Here's a working definition for "aesthetic", to be kept in mind throughout the present paper: following DESIDERI (2013; 2014; 2015; see also DISSANAYAKE, 2014), I claim that human aesthetic attitude is a particular behaviour, triggered by events or objects, that involves attention, emotional investment, energy expenditure, the formulation of a (even implicit) judgement of taste and which is associated with pleasure or displeasure. The aesthetic behaviour, which makes it possible for us to establish a cognitive/affective relationship with the aspectual properties of an object or event (not necessarily a work of art), is a self-rewarding perceptual process, which suspends momentarily the daily perceptive routines, lighting up the world.
} 
far there hasn't been any comprehensive study rigorously looking into the aesthetic (or proto-aesthetic) behaviour of other animals, although a comparative perspective would be highly helpful for understanding the evolution of aesthetic behaviour in humans. Moreover, in adopting a comparative approach, we should not restrict ourselves to the study of primate homologies and similarities, but rather explore analogies wherever they are found in the animal kingdom. Indeed, as Leder and Nadal highlight (LEDER, NADAL 2014), “ our closest living primate relatives produce nothing like art, and appear to lack aesthetic appreciation ". In his The Descent of Man (1871, p. 375) Darwin had written something similar: birds, and not primates, "appear to be the most aesthetic of all animals, excepting of course man, and they have nearly the same taste for the beautiful as we have". Evolutionary biology provides a useful concept to identify the process whereby organisms not closely related (not monophyletic), independently evolve similar traits: convergence. Might it be the case that human aesthetic attitude is the result of a process of convergent evolution?

4) EA still lacks a shared and coherent epistemological and methodological (experimental) framework. The vast majority of EA accounts of the aesthetic attitude remain hypothetical; deriving testable predictions from them is not always easy or even possible. However, as recent researches seem to suggest, the rigorous passage through the "experimental sieve" may be crucial (see MOSING, MIRIAM A. et al., 2015, on the account based on sexual selection). "How - methodologically and epistemologically speaking - philosophical apriori investigations should be integrated with empirical work? ", SCHELLEKENS and GOLDIE (2011) ask at the beginning of their The Aesthetic Mind. The question remains largely unanswered.

For all these reasons, 1), 2), 3), 4) EA, as an interdisciplinary research endeavour, seems not to be able, at the current stage, to provide true theoretical or practical advancements, i.e. it is not effective (Boix Mansilla's third epistemic criterion) and needs to be reassessed and revised.

\section{New challenging avenues in EA}

EA requires more sophisticated conceptual tools than those generally employed today. Focusing in particular on sections 2) and 3) of the previous paragraph, I propose here to take into account two challenging and recent developments in evolutionary biology, epigenetic inheritance (CAREY, 2011) and niche construction theory (ODLING-SMEE et al., 2003), and 
to attempt to integrate them into the theoretical framework of a revised and updated EA. In my view, this might be one of the first steps towards a true evolutionary science of aesthetics.

\section{a) Epigenetics and aesthetic experience}

Most EA studies focus on shared responses among aesthetic perceivers, attributed to hypothetical species-specific human adaptations (BUSS, 2005), rather than explore individual differences and the influence of individual biography and individual experiences on the development of aesthetic preferences and aesthetic attitude.

As is today well known, experiences that humans (and nonhuman animals) collect during their lifetime, the behaviours that they most frequently display and the environment they live in affect, mould and shape their phenotypic expression. This is one of the facets of epigenetics (JABLONKA, LAMB, 2005; CAREY, 2011; PIGLIUCCI, MÜLLER, 2010; MANDRIOLI, 2013), a discipline dealing with the regulation processes of gene expression independent of DNA sequence, and with the role played by environmental pressures (broadly understood) in this regulation. Thanks to epigenetics, we are starting to unravel the missing link between nature and nurture; how our environment talks to us and alters us.

Moving from the assumption that humans do not possess distinct brain regions or genes or gene complexes specifically responsible for processing and decoding aesthetic stimuli (CHATTERJEE, 2014), neuroscientists CHANGEUX (1983) and DEHAENE (2007) and philosopher of aesthetics DESIDERI (2013) claim that the human aesthetic attitude may develop epigenetically, not genetically. Thanks to repeated behaviours, preferences and choices some of our neural pathways "stabilize" and allow us to distinguish easily between beautiful and ugly things, between cute and awkward. At a biological level, examples of epigenetic processes are DNA methylation and histone acetylation (CAREY, 2011) .

\footnotetext{
${ }^{4}$ Thomas Jenuwein in the "Epigenome Network of Excellence" writes: "The difference between genetics and epigenetics can probably be compared to the difference between writing and reading a book. Once a book is written, the text (the genes or DNA: stored information) will be the same in all the copies distributed to the interested audience. However, each individual reader of a given book may interpret the story slightly differently, with varying emotions and projections as they continue to unfold the chapters. In a very similar manner, epigenetics would allow different interpretations of a template and result in different read-outs, dependent upon the variable conditions under which this template is interrogated" (http://www.epigenesys.eu/
} 
A certain number of DNA epigenetic modifications seem to be transmitted to the offspring, that is: sometimes animals do inherit "acquired characteristics" (in our case, proto-aesthetic acquired preferences) from their parents.

We know that the vast majority of the mammal genome gets reset when a sperm and a egg fuse to form a zygote, so that the epigenetic modifications carried from the male gamete and those carried by the female one are striped off very quickly, immediately after the sperm has penetrated the egg. The operating system is, so to speak, reinstalled (CAREY 2011). However, it seems that a small proportion of these parental epigenetic modifications are transmitted from parents to their offspring. For instance, certain stressful situations leave marks that go beyond the immediate individual response; some seem to be passed on to the next generations. The same happens with food and smells and other sensorial-perceptual preferences - in a very minimal sense, aesthetic traits (in mice, for example: RASSOULZADEGAN M. et al., 2006; DIAS, RESSLER, 2013; SZYF, 2014).

Is it possible that at least a small part of (or the fundamental ingredients of) the aesthetic schemes and rules typical of a human community or group of relatives (i.e. preferences for a certain taste, a smell, a figurative style etc.) do stabilize epigenetically and depend on epigenetic mechanisms? Is it possible that - along with other form of sedimentation, stabilization and transmission of aesthetic preferences and aesthetic rules and standards, such as cultural transmission - epigenetics plays a role in the development of an aesthetic behaviour in humans?

The epigenetics of human aesthetics is a very challenging and fascinating research field, on the boundary between nature and nurture, that could help us to eventually get rid of the gene-centred approach that has for too long dominated the discussion in EA, and of the ancient - and unwieldy - dichotomy between nature and nurture.

\section{b) Aesthetic niche}

Modern and contemporary explanations of human aesthetic experience have traditionally oscillated between two conflicting foci: a subjective understanding (as in HUME [1757], who claims that "beauty is no quality in things themselves: It exists merely in the mind which contemplates

en/articles/in-brief/196-definition-of-epigenetics). 
them") and, on the opposite side, a formalistlobjectivistic understanding (as in BELL [1914], claiming that aesthetic experience is almost contextually impermeable) (LEDER, NADAL, 2014). None of these explanations seems fully acceptable (see DESIDERI, 2014): on the one hand, the emergence and unfolding of an aesthetic attitude in humans is, as already claimed by DEWEY (1934), a matter of inherent interaction and perceptual trade between the organism involved and its own environment; on the other hand, and as a methodological constraint from the first statement, aesthetic episodes that occur in a laboratory setting differ to a large extent from those occurring in other contexts (PANKSEPP, BIVEN, 2002; BRIEBER et al., 2014).

The so-called "niche construction theory", in the frame of contemporary Evolutionary theory, with its emphasis on the mutual interactions and feedbacks between organism and environment, between "subject" and "object", "externalist" and "internalist" perspectives (ODLING-SMEE et al., 2003; MENARY, 2014), provides new avenues for research in EA. Rather than the result of a merely subjective experience or, on the contrary, the mere effect of well-grounded properties in the object, the aesthetic is best seen to lie in the (mutual) relation between object and subject ("relational approach"), including a feedback action from the organism to the environment (and not only from the environment to the organism). MENARY (2014) has recently started exploring the full potential of niche construction theory for EA: "Given that there is no "art module" in the brain, we need an account of human evolution that will allow for variability in human behaviour. Secondly we need a model that explains how innovations in our cultural niche are inherited and propagated leading to changes in behaviour over time. The niche construction model explains how both of these causal factors could come into play" (MENARY, 2014, p. 472).

\section{Conclusions}

Those provided above are just two possible examples of the different ways in which the most advanced and challenging research topics in current evolutionary biology can be integrated into a revised and updated EA. There is, however, still a lot of work to be done.

Aesthetics, as I mentioned at the beginning of this article, has been since its formal foundation in the Eighteenth century a boundary discipline. 
One of the greatest challenges facing Aesthetics today is to provide this inherently "double (or multiple)-track" discipline with a defined and rigorous epistemological, theoretical, methodological framework, also paying attention to the ways in which we can derive testable predictions from EA theories and interpretations. As Leder, Nadal (2014) remark in their highly valuable paper, it is time to take a decisive step towards a true interdisciplinary (neuro-, evolutionary and cognitive) science of Aesthetics. I couldn't agree more. However, before going to the heart of this inter-disciplinary matter, I suggest that we should first get rid of the main misunderstandings already existing in the field. That is what I have attempted to start doing with this overview.

\section{References}

AVANESSIAN, A.; MENNINGHAUS, W.; VÖLKER, J. (Eds.). Vita aesthetica. Szenarien ästhetischer Lebendigkeit. Zürich-Berlin: Diaphanes, 2009.

BARKOW, J. H.; COSMIDES, L.; TOOBY, J. (Eds.). The Adapted Mind: Evolutionary Psychology and the Generation of Culture. New York: Oxford University Press, 1992.

BELL., C.; FREDERICK A. Art. New York: Stokes Company, 1914.

BOIX MANSILLA, V. Interdisciplinary Work at the Frontier: An Empirical investigation of Expert Interdisciplinary Epistemologies. Issues in Integrative Studies, n. 24, p. 1-31, 2006 a.

. Symptoms of Quality - Assessing Interdisciplinary Work at the Frontier: An Empirical Exploration. Research Evaluation, n. 15, v. 1, p. 17-29, 2006b.

BOLHUIS, J. J. et al. Darwin in Mind: New Opportunities for Evolutionary Psychology. PLoS Biology, n. 9, v. 7, e1001109, 2011.

BRIEBER, D. et al. Art in Time and Space: Context Modulates the Relation Between Art Experience and Viewing Time. PLoS ONE, n. 9, v. 6, e99019, 2014.

BULLER, D. Adapting Minds: Evolutionary Psychology and the Persistent Quest for Human Nature. Cambridge (MA): MIT Press, 2005.

BURKE, E. A Philosophical Enquiry into the Origin of Our Ideas of the Sublime and Beautiful. Oxford: Oxford University Press, [1757] 1998. 
BUSS, D. The Handbook of Evolutionary Psychology. London: Wiley, 2005.

CAREY, N. The Epigenetics Revolution. How Modern Biology Is Rewriting Our Understanding of Genetics, Disease and Inheritance. London: Icon Books, 2011.

CARROLL, J. Literary Darwinism: Evolution, Human Nature, and Literature. London-New York: Routledge, 2004.

. The Adaptive Function of the Arts: Alternative Evolutionary Hypotheses. In: C. Gansel, D., Vanderbeke (Eds.). Telling Stories: Literature and Evolution. Berlin: De Gruyter, 2012, p. 50-63.

. Dutton, Davies and Imaginative Virtual Worlds: The Current State of Evolutionary Aesthetics. Aisthesis. Pratiche, linguaggi e saperi dell'estetico, n. 6, v. 2, p. 81-93, 2013.

CHANGEUX, J.-P. L'homme neuronal. Paris: Fayard, 1983.

ChATterJeE, A. The Aesthetic Brain. How We Evolved to Desire Beauty and Enjoy Art. Oxford: Oxford University Press, 2014.

CROFT, J. The Challenges of Interdisciplinary Epistemology in Neuroaesthetics. Mind, Brain and Education, n. 5, v. 1, p. 5-11, 2011.

DARWIN, C. R. On the Origin of Species by Means of Natural Selection, or the Preservation of Favoured Races in the Struggle for Life. London: John Murray, 1859 [1872].

The Descent of Man, and Selection in Relation to Sex. London: John Murray, 1871.

DAVIES, S. The Artful Species. Aesthetics, Art and Evolution. Oxford: Oxford University Press, 2012.

DEACON, T. A Role for Relaxed Selection in the Evolution of the Language Capacity. PNAS, n. 107, v. 2, p. 9000-9006, 2010.

DEHAENE, S. Les Neurones de la lecture. Paris: Édition Odile Jacob, 2007.

D'ERRICO, F.; HENSHILWWOD, C.S. Homo Symbolicus: The Dawn of Language, Imagination and Spirituality. Amsterdam-Philadelphia: John Benjamins Publishing, 2011.

DESIDERI, F. On The Epigenesis of the Aesthetic Mind. The Sense of Beauty from Survival to Supervenience. Rivista di estetica, n. 54, v. 3, p. 63-82, 2013. 
. Epigenesis and Deduction of the Aesthetic Judgement. Before and Beyond the Old Dichotomy. Paper presented at the VIth Mediterranean Congress of Aesthetics, Florence, June $24^{\text {th }}-28^{\text {th }}, 2014$.

DEWEY, J. Art as Experience. New York: Putnam, 1934.

DIAS, B. G.; RESSLER, K. J. Parental Olfactory Experience Influences Behavior and Neural Structure in Subsequent Generations. Nature Neuroscience, n. 9, December 2013.

DISSANAYAKE, E. What Is Art For? Seattle: University of Washington Press, 1988.

. Homo aestheticus. Where Art Comes From and Why. New York: Free Press, 1992.

. A Bona Fide Ethological View of Art: The Artification Hypothesis. In.: C. Sütterlin, W. Schiefenhövel, ed., C. Lehmann, J. Forster, G. Apfelauer (Eds.). Art As Behaviour: An Ethological Approach to Visual and Verbal Art, Music and Architecture. Hanse Studies, n. 10, BIS Verlag Oldenburg, p. 42-60, 2014.

DUTTON, D. The Art Instinct: Beauty, Pleasure, and Human Evolution. New York: Bloomsbury Press, 2009.

GOULD, S. J.; VRBA, E. Exaptation. A Missing term in the Science of Form. Paleobiology, n. 8, p. 4-15, 1982.

GOULD, S. J. The Structure of Evolutionary Theory. Cambridge (MA): Harvard University Press, 2002.

HUME, D. On the Standard of Taste. Cambridge: LibertyClassics, [1757] 1987.

JABLONKA, E.; LAMB, M. Evolution in Four Dimensions. Genetic, Epigenetic, Behavioral and Symbolic Variation in the History of Life. Cambridge (MA): Massachusetts Institute of Technology, 2005.

KANT, I. Kritik der Urteilskraft. Stuttgart: Reclam, [1790] 1986.

KAWABATA, H., ZEKI S. Neural Correlates of Beauty. Journal of Neurophysiology, n. 91, p. 1699-1705, 2004.

KOHN, D. The Aesthetic Construction of Darwin's Theory. In.: Tauber A. The Elusive Synthesis. Aesthetics and Science. Dordrecht: Kluwer, 1996, p. 13-48.

LEDER, H.; BELKE, B.; OEBERST, A.; AUGUSTIN, D. A Model of Aesthetic Appreciation and Aesthetic Judgements. British Journal of Psychology, n. 95, p. 489-508, 2004. 
LEDER, H. Next Steps in Neuroaesthetics: Which Processes and Processing Stages to Study? Psychology of Aesthetics, Creativity, and the Arts, n. 7, p. 27-37, 2013.

LEDER, H.; NADAL, M. Ten Years of a Model of Aesthetic Appreciation and Aesthetic Judgments: The Aesthetic Episode - Developments and Challenges in Empirical Aesthetics. British Journal of Psychology, p. 443464, 2014.

LEWIS, D.; RUSSELL, E.; AL-SHAWAF, L.; BUSS, D. Lumbar Curvature: a Previously Undiscovered Standard of Attractiveness. Evolution and Human Bahavior, 2015, doi: http://dx.doi.org/10.1016/j. evolhumbehav.2015.01.007

MANDRIOLI, M. Not By our Genes Alone. Aisthesis. Pratiche, linguaggi e saperi dell'estetico, n.6, v.2, p. 21-29, 2013.

MENARY, R. The Aesthetic Niche: Commentary on The Artful Species. British Journal of Aesthetics, n. 54, v. 4, p. 471-475, 2014.

MENNINGHAUS, W. Biology à la mode: Charles Darwin's Aesthetics of "Ornament". History and philosophy of life sciences, n. 31, p. 263-278, 2009.

2011.

Wozu Kunst? Ästhetik nach Darwin. Berlin: Suhrkamp Verlag,

MILLER, G. F. The Mating Mind: How Sexual Choice Shaped the Evolution of Human Nature. New York: Doubleday, 2000.

MITHEN, S. The Prehistory of Mind. A Search for the Origins of Art, Religion and Science. London: Thames and Hudson, 1996.

MOSING, Miriam A. et al. Did Sexual Selection Shape Human Music? Testing Predictions from the Sexual Selection Hypothesis of Music Evolution Using a Large Genetically Informative Sample of Over 1.000 Twins. "Evolution and Human Behavior", n. 36/5, p. 359-366, September 2015.

ODLING-SMEE, F. J.; LALAND, K. N.; FELDMAN M. W. Niche Construction. The Neglected Process in Evolution. Princeton Oxford : Princeton University Press, 2003.

ORIANS, G. H. An Ecological and Evolutionary Approach to Landscape Aesthetics. In: Penning-Rowsell E. C., Lowenthal D. (Eds.). Landscape Meanings and Values. London : Allen and Unwin, 1986, p. 3-25.

PANKSEPP, J.; BIVEN, L. The Archeology of Mind. Neuroevolutionary 
Origins of Humans Emotions. New York London : W. W. Norton \& Company, 2012.

PIGLIUCCI, M.; MÜLlER, G. B. Evolution. The Extended Synthesis. Cambridge (MA) : The MIT Press, 2010.

PINKER, S. How the Mind Works. New York London : W. W. Norton \& Company, 1997.

PRUM, R. Aesthetic Evolution by Mate Choice: Darwin's Really Dangerous Idea. "Philosophical Transactions of the Royal Society of London B: Biological Sciences”, n. 367, p. 2253-2265, 2012.

RASSOULZADEGAN, $M$. et al. RNA-mediated Non-mendelian Inheritance of An Epigenetic Change in the Mouse. "Nature", n. 441, p. 469-474, 2006.

RICHARDSON, R. C. Evolutionary Psychology as Maladapted Psychology. Cambridge (MA) : The MIT Press, 2007.

ROTHENBERG, D. The Survival of the Beautiful. Art, Science and Evolution. London : Bloomsbury, 2011.

SCHELLEKENS, E.; GOLDIE, P. (Eds.). The Aesthetic Mind: Philosophy and Psychology. Oxford : Oxford University Press, 2011.

SCHER, S.; RAUSCHER, M. (Eds.). Evolutionary Psychology: Alternative approaches. Berlin : Springer, 2003.

SZYF, M. Lamarck Revisited: Epigenetic Inheritance of Ancestral Odor Fear Conditioning, "Nature Neuroscience", n. 17, p. 2-4, doi: 10.1038/ nn.3603, 2014.

TOOBY, J.; COSMIDES L. Does Beauty Build Adapted Minds? Toward an Evolutionary Theory of Aesthetics, Fiction and Arts. "SubStance", n. 94/95, p. 6-27, 2001.

VOLAND, E.; GRAMMER, K. (Eds.). Evolutionary Aesthetics. Berlin : Springer, 2003.

VOLAND, E.; RUSCH, H. Evolutionary Aesthetics: an Introduction to Key Concepts and Current Issues. "Aisthesis. Pratiche, linguaggi e saperi dell'estetico", n. 6/2, p. 113-133, 2013.

WELSCH, W. Animal Aesthetics. "Contemporary Aesthetics", n. 2, 2004 (on-line: <https://contempaesthetics.org/newvolume/pages/article. php?articleID=243> last accessed: april 2019).

WELSCH, W. Blickwechsel. Neue Wege der Aesthetik, Stuttgart, Reclam, 2012. 
ZEKI, S. A Vision of the Brain. Oxford : Blackwell, 1993.

ZEKI, S. Splendors and Miseries of the Brain: Love, Creativity, and the Quest for Human Happiness. Oxford : Blackwell, 2008. 